\title{
Efektivitas Penambahan Bahan Pengenyal yang Berbeda Terhadap Nilai Organoleptik dan pH Bakso Daging Ayam Broiler
}

\author{
Effectiveness of Adding Different Chewing Materials to the Organoleptic and \\ $p H$ value of Broiler Chicken Meatballs
}

\author{
Akbar*, Intan Dwi Novieta, Fitriani \\ Program Studi Peternakan, Fakultas Pertanian, Peternakan dan Perikanan, Universitas \\ Muhammadiyah Parepare, 91132, Sulawesi Selatan, Indonesia \\ *Korespondensi Email: akbarpeternakan26@gmail.com
}

\begin{abstract}
ABSTRAK
Tujuan penelitian ini adalah untuk mengetahui pengaruh penambahan bahan pengenyal yang berbeda terhadap nilai organoleptik dan $\mathrm{pH}$ bakso daging ayam broiler. Penelitian ini menggunakan rancangan acak lengkap pola faktorial dengan 4 perlakuan dan 3 ulangan dimana faktor $\mathrm{T}$ (konsentrasi). Adapun faktor T (konsentrasi) yaitu T1 (15 g), T2 (10 g), dan T3 (7 g) Adapun hasil penelitian menunjukkan bahwa penambahan bahan pengenyal yang berbeda berpengaruh sangat nyata $(\mathrm{P}<0,01)$ terhadap nilai uji organoleptik daging ayam broiler. Adapun penambahan bahan pengenyal yang berbeda terhadap uji organoleptik bakso daging ayam broiler berpengaruh sangat nyata $(P<0,01)$ terhadap uji organoleptik aroma, rasa, tekstur dan kekenyalan. Sedangkan untuk $\mathrm{pH}$ tidak berpengaruh nyata $(\mathrm{P}>0,05)$ terhadap $\mathrm{pH}$ bakso daging ayam broiler.
\end{abstract}

Kata kunci: Bahan Pengenyal, Bakso, Broiler, Uji Organoleptik dan Nilai pH

\begin{abstract}
ABSTRAK
The purpose of this study was to determine the effect of adding different thickening agents to the organoleptic value and $\mathrm{pH}$ of meatballs of broiler chicken meat. This study uses a completely randomized design factorial pattern with 4 treatments and 3 replications where the $\mathrm{T}$ factor (concentration). The $\mathrm{T}$ factor (concentration), namely T1 (15 g), T2 (10 gr), and T3 (7 g) The results of the study showed that the addition of different thickening ingredients had a very significant effect $(\mathrm{P}<0.01)$ on the organoleptic test values of meat broiler chicken. And the addition of a different thickening agent to the organoleptic test of roiler chicken meatballs has a very significant effect $(\mathrm{P}<0.01)$ on the organoleptic test of aroma, taste, texture and suppleness. Whereas the $\mathrm{pH}$ was not significant $(\mathrm{P}>0.05)$ on the $\mathrm{pH}$ of meatballs of broiler chicken meat.
\end{abstract}

Keywords: Chewing Agent, Meatballs, Broiler, Organoleptic Test and pH, Value

\section{PENDAHULUAN}

Daging ayam merupakan salah satu komoditas peternakan yang memiliki nilaigizi sejajar dengan nilai gizi daging lainnya. Pada tahun 2017, konsumsi ayam diperkirakan meningkat hingga 15 persen atau mencapai 9,7 kg per kapita, dan bahkan akan mencapai 
angka 14,99 kg per kapita di tahun 2018 mendatang. Berdasarkan perkiraan peningkatan konsumsi sebesar 97 persen yang dapat dicapai dalam waktu 3 tahun dari sekarang, akan sangat menjanjikan keuntungan bagi emiten yang bergerak di bidang peternakan unggas (BPS, 2017).

Daging sering kita jumpai dalam kehidupan sehari-hari, karena daging merupakan bahan pangan yang berasal dari hewani dan banyak yangmengkonsumsi. Daging merupakan salah satu komoditi peternakan yangdibutuhkan untuk memenuhi kebutuhan protein hewani karena mengandungprotein bermutu tinggi dan mampu memenuhi zat gizi yang dibutuhkan oleh tubuh. Selain itu, daging juga mengandung karbohidrat, lemak, vitamin, dan mineral

Mutu dan kualitas daging akan mengalami penurunan dapat dicegahdengan cara penanganan dan pengolahan. Salah satu hasil pengolahan daging adalah bakso. Bakso adalah produk makanan berbentuk bulat atau lainnya yang diperoleh dari campuran daging ternak (kadar daging tidak kurang dari50\%) dan pati atau serealia dengan atau tanpa penambahan bahan makananlain, serta bahan tambahan makanan yang diijinkan.

Bakso merupakan salah satu produk olahan hasil ternak yang bergizi tinggidan banyak digemari masyarakat. Produk olahan bakso pada umumnyamenggunakan bahan baku daging dan tepung. Daging yang biasanya dipakaiadalah sapi, ayam dan ikan sedangkan tepung yang biasanya dipakai yaitutepung tapioka. Penggunaan daging selain ketiga sumber tersebut, sebelumlazim dilakukan dan akan memunculkan suatu peluang usaha baru yang dapatmenciptakan varian baru produk bakso.

Faktoryang berpengaruh pada kualitas bakso adalah kualitas daging,bahan mentah, tepung yang digunakan, bahan-bahan tambahan danperbandingan adonan serta cara pemasakan.Putih telur yang jumlahnya sekitar $60 \%$ dari seluruh bulatan telur mengandung protein dan sedikit karbohidrat. Putih telur saat ini telah banyak digunakan dalam industri makanan, karena sifat daya busa putih telur yang dapat meningkatkan kualitas produk pangan.

Karagenan berasal dari rumput laut yang mengandung protein dan meningkatkan kadar air. Keragenan dapat menyerap air sehingga menghasilkan tekstur yang kompak,dan dapat meningkatkan daya ikat air. Karagenan dapat juga diaplikasikan pada berbagai produk sebagai pengontrol kadar air (Keton, 2001). 
Agar-agar sebagai pengenyal bakso ini memiliki kandungan yang alami dan berserat tinggi, maka sangat baik bila digunakan untuk pengenyal bakso khususnya daging ayam broiler. tetapi karena spesifikasi agar-agar sangat beragam, ada yang untuk mie, es krim, yoghurt, bakso dan lain-lain, Adapun kadar pemakaiannya 1-2\% dari berat total adonan (Rahayu, 2006).

Sehubungan dengan uraian tersebut maka dilakukan penelitian mengenai pengaruh penambahan agar-agar, putih telur dan keragenan sebagai bahan pengenyal yang berbeda terhadap nilai organoleptik dan $\mathrm{pH}$ bakso daging ayam broiler.

\section{METODE}

Penelitian ini menggunakan Rancangan Acak Lengkap (RAL) dengan 4 perlakuan dan 3 ulangan. Perlakuan yang diterapkan adalah: T0=Bakso ayam tanpa penambahan pengenyal (kontrol), T1=Penambahan Putih telursebagai bahan pengenyal $15 \mathrm{~g} / \mathrm{kg}$, T2 = Penambahan Karagenansebagai bahan pengenyal $10 \mathrm{~g} / \mathrm{kg}, \mathrm{T} 3=$ Penambahan Agar agar sebagai bahan pengenyal $7 \mathrm{~g} / \mathrm{kg}$

\section{Analisis Data}

Data yang diperoleh dari panelitian ini dihitung dengan menggunakan Rancangan Acak Lengkap (RAL) menurut Gazpersz (1991).

\section{HASIL DAN PEMBAHASAN}

\section{Warna}

Hasil rata-rata tingkat uji organoleptik (warna) bakso daging ayam broiler pada level penambahan bahan pengenyal yang berbeda di sajikan dalam Gambar 1. Berdasarkan hasil analisis ragam menunjukkan bahwa penambahan bahan pengenyal yang berbeda berpengaruh sangat nyata $(\mathrm{P}<0,01)$ terhadap warna bakso daging ayam broiler. Adapun nilai rata-rata dari setiap perlakuan yaitu yaitu T0 (2.80), T1 (3.30) T2 (3.90) T3 (3.06). Hasil analisis uji wilayah berganda Duncan, yaitu T0 berbeda sangat nyata dengan T1, T2 dan T3 T1, berbeda sangat nyata dengan T0 berbeda sangat nyata dengan T2 dan T3, T2 berbeda sangat nyata dengan T0 berbeda sangat nyata dengan T1 dan T3, T3 berbeda sangat nyata dengan T0 berbeda sangat nyata dengan T1 dan T2.

Perubahan tigkat nilai warna pada bakso dapat dilihat dari nilai ratar-rata setiap perlakuan, dimana nilai rata-rata dari setiap perlakuan, yaitu T0 (2.80), T1 (3.3), T2 (3.90) 
dan T3 (3.06). perubahan tersebut dipengaruhi oleh pigmen pembentuk warna alami pada bahan pengenyal yang bebeda.

Adapun hasil yang terbaik diperoleh pada perlakuan T2 dengan penambahan karagenan sebagai bahan pengenyal karena memiliki warna keabu-abuan dan nilai tertinggi dibandingkan perlakuan yang lain. karagenan adalah berasal dari rumput laut yang mengandung protein dan meningkatkan kadar air. sehingga tidak merubah warna bakso daging ayam. Warna bakso daging ayam dengan bahan pengenyal yang berbeda lebih dipengaruhi oleh warna daging ayam lebih banyak ditentukan oleh miglobin dan hemoglobin dalam daging. Daging ayam termasuk daging putih sehingga pada saat dimasak bakso dading ayam akan berubah menjadi putih keabuan (Nafly,2011).

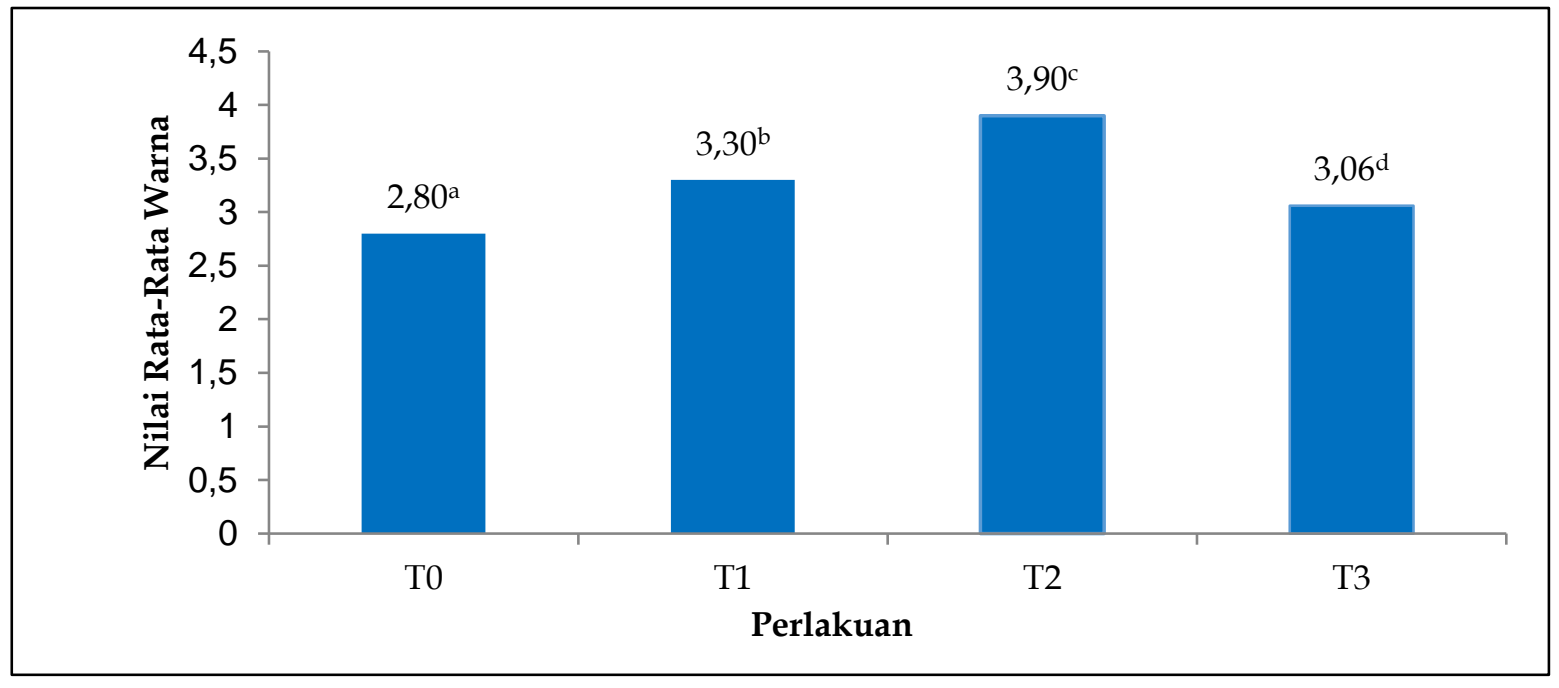

Gambar 1. Nilai Rata-Rata Warna pada Bakso Daging Ayam Broiler Berdasarkan Level Penambahan Bahan Pengenyal yang Berbeda. Superskrip yang berbeda pada diagram batang yang sama menunjukkan berpengaruh sangat nyata $(\mathrm{P}<0,01)$ untuk uji organoleptik (warna)).

\section{Rasa}

Rata-rata tingkat uji organoleptik (rasa) bakso daging ayam broiler pada level penambahan bahan pengenyal yang berbeda di sajikan dalam Gambar 2. Berdasarkan hasil analisis ragam menunjukkan bahwa penambahan bahan pengenyal yang berbeda berpengaruh sangat nyata $(\mathrm{P}<0,01)$ terhadap rasa bakso daging ayam broiler. Adapun nilai rata-rata dari setiap perlakuan yaitu T0 (2.53), T1 (3.03) T2 (3.90) T3 (3.06). Pada hasil analisis uji wilayah berganda Duncan, yaitu T0 berbeda sangat nyata dengan T1, 
T2 dan T3 T1, berbeda sangat nyata dengan T0 dan T2 tetapi tidak berbeda nyata dengan T3, T2 berbeda nyata dengan T0, T1 dan T3, T3 berbeda nyata dengan T0 tetapi tidak berbeda nyata dengan T1 tetapi berbeda nyata dengan T2.

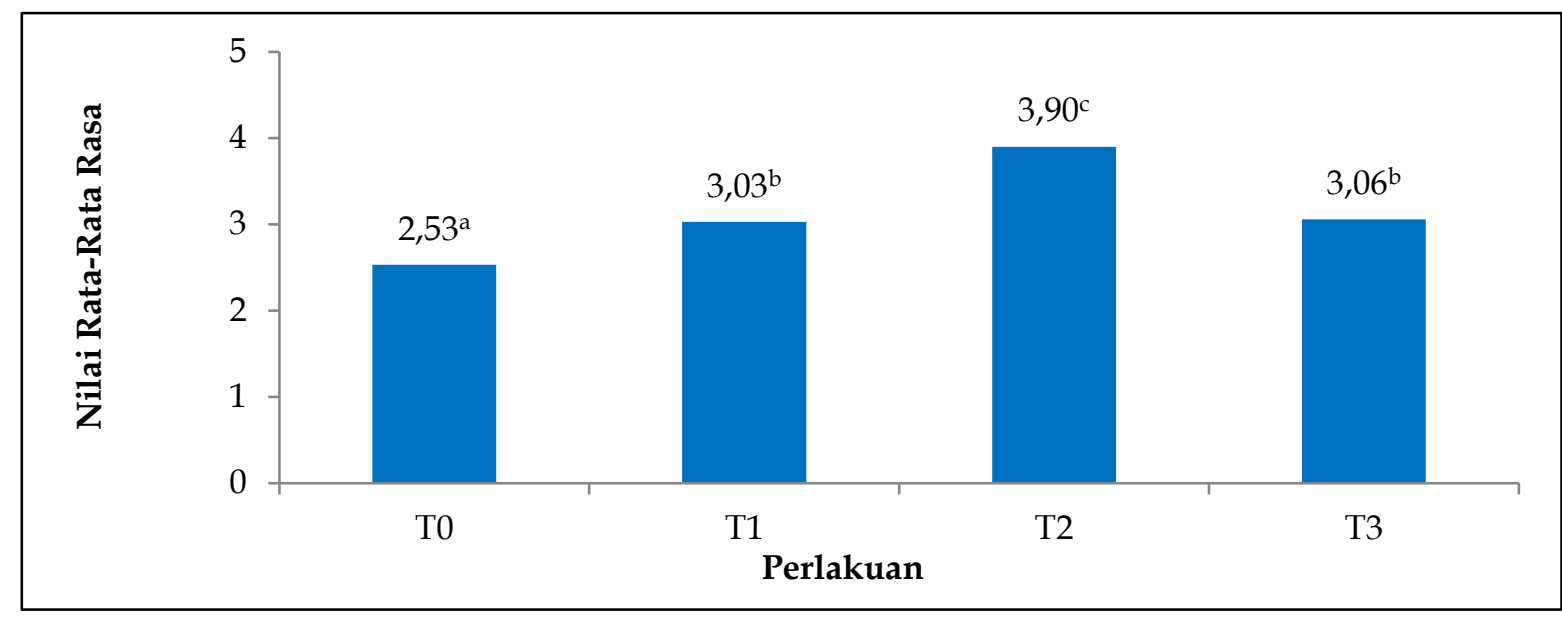

Gambar 2. Tabel 2. Nilai Rata-Rata Rasa pada Bakso Daging Ayam Broiler Berdasarkan Level Penambahan Bahan Pengenyal yang Berbeda. Superskrip yang berbeda pada diagram batang yang sama menunjukkan berpengaruh sangat nyata $(\mathrm{P}<0,01)$ untuk uji organoleptik (rasa).

Berdasarkan hasil penelitian hal ini menunjukkan bahwa level konsentrasi yang berbeda mempengaruhi rasa bakso daging ayam broiler. Semakin tinggi nilai yang tertera pada diagram batang semakin bagus rasa pada bakso daging ayam broiler. Skor nlai rasa pada bakso 1= sangat tidak suka, 2 tidak suka 3 agak suka 4 suka 5 sangat suka.

Perlakuan yang terbaik terdapat pada penambahan bahan pengenyal karagenan karena memiliki nilai tertinggi dari perlakuan yang lain. karagenan merupakan produk utama yang dihasilkan dari rumput laut sehingga menambah cita rasa bakso daging ayam broiler. Agar-agar bersifat dehidrasi (menghilangkan air), karena air dan kandungan asamnya akan bereaksi dan menghasilkan gas, yang akan hilang saat mengembangnya bahan, sehingga mempunyai nilai rasa yang kurang (mengarah ke agak suka) (Nafly, 2011).

\section{Tekstur}

Rata-rata tingkat uji organoleptik (tekstur) bakso daging ayam broiler pada level penambahan bahan pengenyal yang berbeda di sajikan dalam Gambar 3. Berdasarkan hasil analisis ragam menunjukkan bahwa penambahan bahan pengenyal yang berbeda 
berpengaruh sangat nyata $(\mathrm{P}<0,01)$ terhadap tekstur bakso daging ayam broiler. Adapun nilai rata-rata dari setiap perlakuan yaitu T0 (2.60), T1 (3.13) T2 (3.95) T3 (2.3). Pada hasil analisis uji wilayah berganda Duncan, yaitu T0 berbeda sangat nyata $(\mathrm{P} 0,01)$ dengan T1 dan T2 tetapi tidak berbeda nyata T3 T1, berbeda sangat nyata dengan T0, T2 dan T3, T2 berbeda sangat nyata dengan T0, T1 dan T3, T3 tidak berbeda nyata dengan T0 tetapi berbeda sangat nyata dengan T1 dan T2.

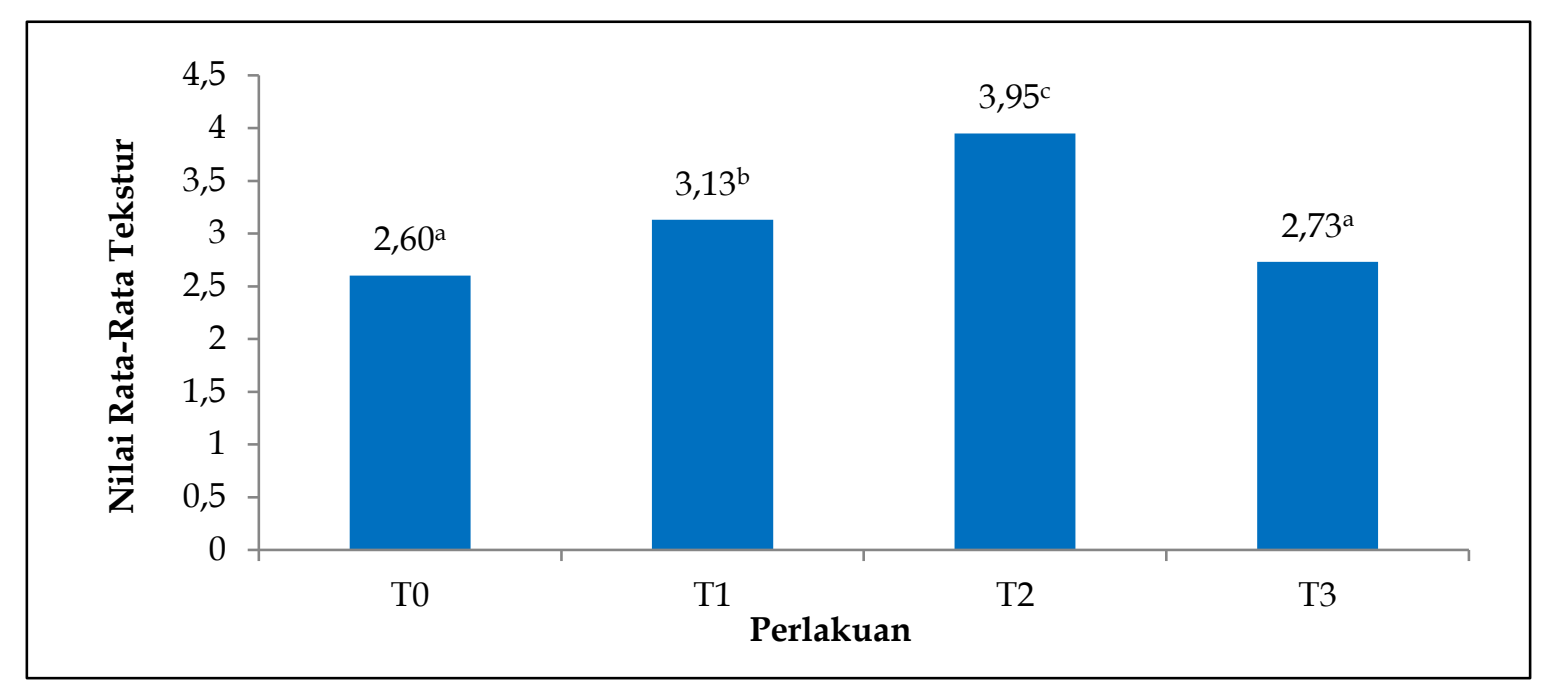

Gambar 3. Nilai Rata-Rata Tekstur pada Bakso Daging Ayam Broiler Berdasarkan Level Penambahan Bahan Pengenyal yang Berbeda. Superskrip yang berbeda pada diagram batang yang sama menunjukkan berpengaruh sangat nyata $(\mathrm{P}<0,01)$ untuk uji organoleptik (tekstur).

Adapun perlakuan dengan tekstur yang terbaik yaitu pada perlakuan T2 penambahan karagenan sebagai pengenyal.Karagenan merupakan emulsifier alami hasilekstraksi dari rumput laut merah(Kappaphycus alvarezii). Selain menjagaemulsi minyak dalam air pada bakso,karagenan juga dapatmemperbaiki teksturbakso sehingga lebih kenyal (Candra dkk.,2014). Menurut Sitanggang (2015), karagenanmampu membentuk gel sehinggamenyebabkan tekstur lebih kenyal seiringpenambahan karagenan. Menurut Sidi (2014)pembentukan gel oleh karagenan yaitu suatufenomena penggabungan atau pengikatansilang rantai-rantai polimer sehingga terbentuksuatu jala tiga dimensi yang kuat dan kaku. 


\section{Kekenyalan}

Rata-rata tingkat uji organoleptik (kekenyalan) bakso daging ayam broiler pada level penambahan bahan pengenyal yang berbeda di sajikan dalam Gambar 4. Berdasarkan hasil analisis ragam menunjukkan bahwa penambahan bahan pengenyal yang berbeda tidak berpengaruh nyata $(\mathrm{P}<0,01)$ terhadap kekenyalan bakso daging ayam broiler. Adapun nilai rata-rata dari setiap perlakuan yaituT0 (2.75), T1 (3.16) T2 (3.99) T3 (3.00). Pada hasil analisis uji wilayah berganda Duncan, yaitu T0 berbeda nyata dengan T1, T2 dan T3 T1, berbeda nyata dengan T0 dan T2 tetapi tidak berbeda nyata dengan T3, T2 berbeda nyata dengan T0, T1 dan T3, T3 berbeda nyata dengan T0 tetapi tidak berbeda nyata dengan T1 tetapi berbeda nyata dengan T2.

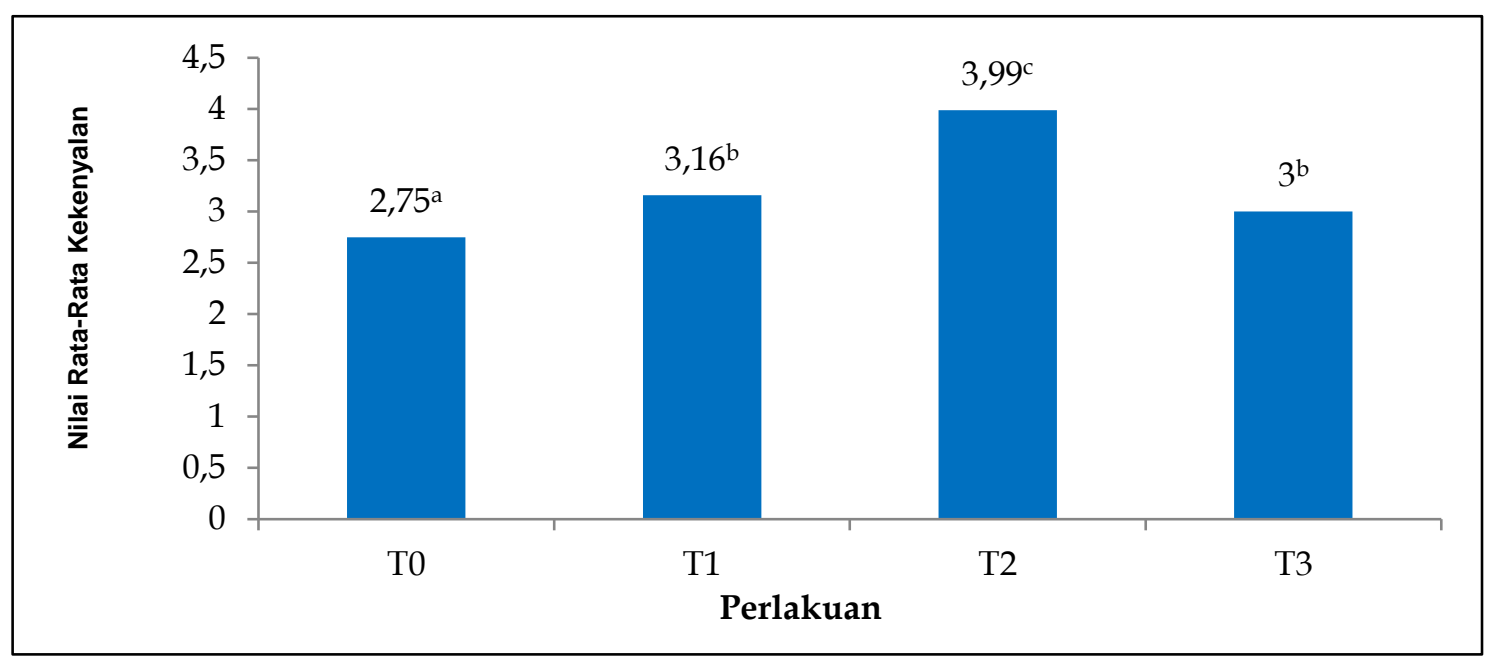

Gambar 4. Nilai Rata-Rata Kekenyalan pada Bakso Daging Ayam Broiler Berdasarkan Level Penambahan Bahan Pengenyal yang Berbeda. Superskripang berbeda pada diagram batang yang sama menunjukkan berpengaruh sangat nyata $(\mathrm{P}<0,01)$ untuk uji organoleptik (kekenyalan).

Berdasarkan hasil penelitian hal ini menunjukkan bahwa level konsentrasi yang berbeda mempengaruhi kekenyalan bakso daging ayam broiler. Semakin tinggi nilai yang tertera pada diagram batang semakin bagus rasa pada bakso daging ayam broiler. Skor nilai rasa pada bakso 1 = sangat tidak kenyal, = 2 tidak kenyal, $=3$ agak kenyal, = 4 kenyal, = 5 sangat kenyal.

Perlakuan dengan kekenyalan yang terbaik terdapat pada T2 penambahan bahan pengenyal karagenan. Penggunaan karagenan dapatmembantu pembentukan gel (dipengaruhioleh tipe dan konsentrasi karagenan sertaadanya ion-ion) dan memperbaiki 
sifatkekenyalan.Karagenan dapat berikatanbaik antara protein dan air, sehinggabakso memiliki kekuatan menahan.tekanan dari luar. Hal ini sejalan denganyang diungkapkan oleh Keeton (2001) bahwa, adanya sejumJah air pada baksoberpengaruh terhadap kekenyalan yang disebabkan air, lemak dan tersedianya basil ekstraksi protein yang menyebabkanterjadinya emulsi, sehingga bakso menjadi lebih kompak dan tidak pecah.

Semakin banyak penambahan karagenan maka bakso semakin kenyal dikarenakan karagenan dapat mengikat bahan pada bakso. karagenan berfungsi memberikan kenampakan yang baik pada bakso, serta sebagai penstabil dan pengiat bahan tambahan agar diperolah bakso yang kenyal (Suarti, 2016).

\section{pH Bakso}

Rata-rata tingkat $\mathrm{pH}$ (kekenyalan) bakso daging ayam broiler pada level penambahan bahan pengenyal yang berbeda di sajikan dalam Gambar 5. Berdasarkan hasil analisis ragam menunjukkan bahwa penambahan bahan pengenyal yang berbeda tidak berpengaruh nyata $(\mathrm{P}>0,05)$ terhadap $\mathrm{pH}$ bakso daging ayam broiler. Adapun nilai rata-rata dari setiap perlakuan yaitu T0 (6.00), T1 (6.43) T2 (6.50) T3 (6.46). Pada hasil analisis uji wilayah berganda Duncan, yaitu T0 tidak berbeda nyata dengan T1, T2 dan T3 T1, tidak berbeda nyata dengan T0 tetapi tidak berbeda nyata dengan T2 dan T3, T2 tidak berbeda nyata dengan T0 tetapi tidak berbeda nyata dengan T1 dan T3, T3 tidak berbeda nyata dengan T0 tetapi tidak berbeda nyata dengan T1 dan T2. Adapun nilai rata-rata dari setiap perlakuan yaitu T0 (6.00), T1 (6.43) T2 (6.50) T3 (6.46).

Berdasarka hasil penelitian hal ini menunjukkan bahwa level konsentrasi yang berbeda tidak mempengaruhi $\mathrm{pH}$ bakso daging ayam broiler. Nilai $\mathrm{pH}$ yang terbaik diperoleh diperlakuan T2 dengan penambahan bahan pengenyal karagenan. Menurut Abadi (2004), nilai pH adonan daging dipengaruhi oleh bahan-bahan yang digunakan, terutama $\mathrm{pH}$ daging yang digunakan. Jika $\mathrm{pH}$ adonan tinggi, adonan akan menjadi padat, kenyal dan alastis. Nilai $\mathrm{pH}$ menentukan kualitas produk bakso, nilai $\mathrm{pH}$ pangan menurut Standarisasi Nasional Indonesia yaitu berkisar 6 sampai 7 pH menurut Standar Nasional Indonesia (Bourne,2002). 


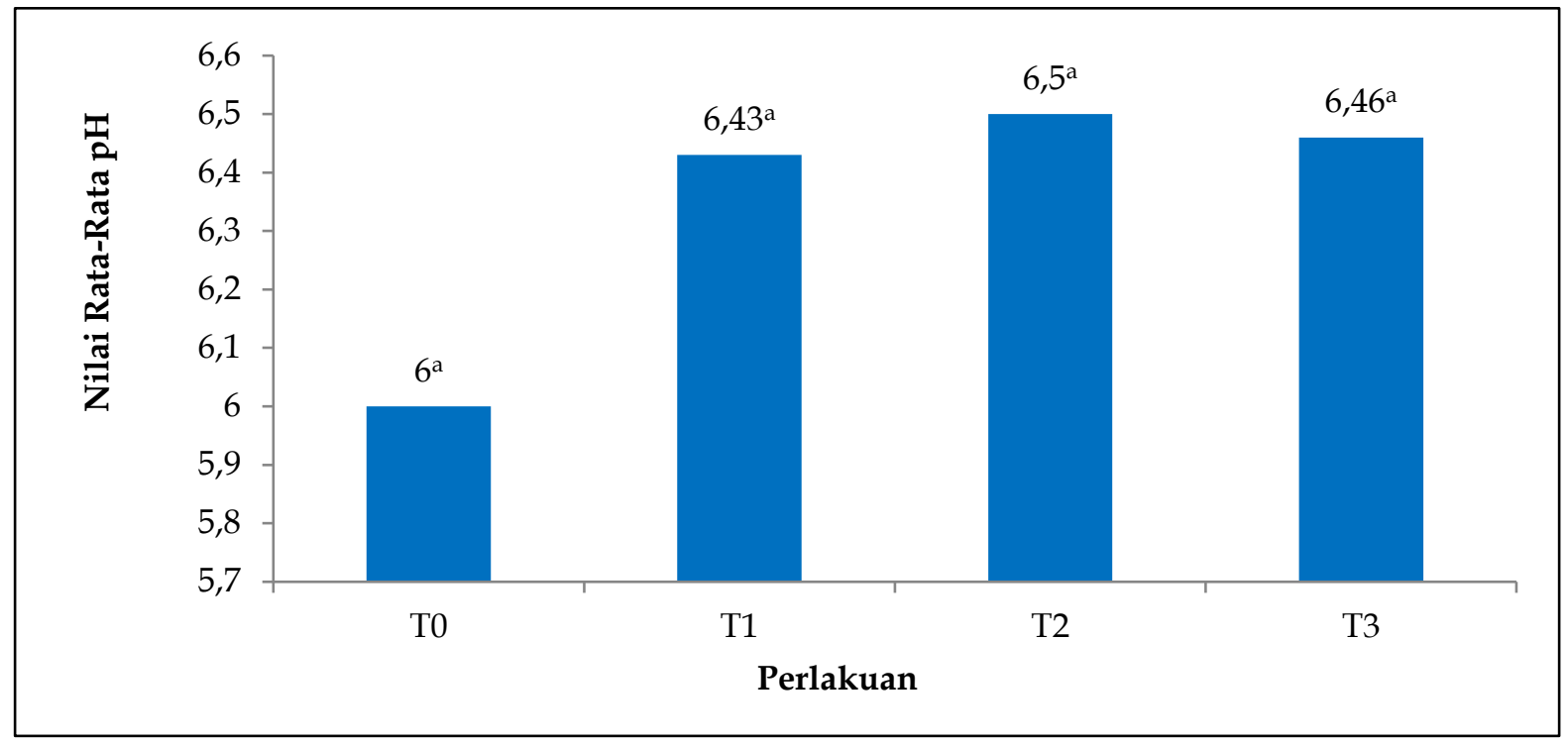

Gambar 5. Nilai Rata-Rata pH Pada Bakso Daging Ayam Broiler Berdasarkan Level Penambahan Bahan Pengenyal yang Berbeda. Superskrip yang berbeda pada diagram batang yang sama menunjukkan tidak berpengaruh nyata $(\mathrm{P}>0,05)$ untuk uji $\mathrm{pH}$.

\section{KESIMPULAN}

Berdasarkan hasil penelitian dapat disimpulkan bahwa penambahan bahan pengenyal yang berbeda memberikan pengaruh terhadap nilai organoleptik dan $\mathrm{pH}$ bakso daging ayam broiler. Hasil yang terbaik terdapat pada perlakuan T2penambahankaragenan 10 gram karena memiliki nilai tertinggi dibandingkan perlakuan yang lain. dengan nilai rata-rata untuk warna putih keabuan 3.90, rasa suka 3.90, tekstur halus 3.95, kekenyalan kenyal 3.99 dan pH 6.50.

Disarankan penelitian lanjutan dengan penambahan bahan pengenyal dengan konsentrasi yang lebih tinggi agar diperoleh nilai uji organoleptik dan $\mathrm{pH}$ yang lebih baik pada bakso daging ayam broiler.

\section{DAFTAR PUSTAKA}

Bourne, M.C. 2002. Food Texture and Viscocity: Concept and Measurement. 2ed. Academic Press an Elsevier Science, London.

Candra, F.N., Riyadi, P.H., dan Wijayanti, I. 2014. Pemanfaatan karaginan (Euchema cottoni) sebagai emulsifierterhadap kesetabilan bakso ikan nila (Oreochromis nilotichus) pada penyimpanan suhu dingin. Jurnal Pengolahan dan Bioteknologi Hasil Perikanan, 3(1), 167-176 
Deptan. 2013. Inovasi teknologi dan pengolahan telur asap"lurik".http:// epetani.deptan.go.id/berita/inovasi-teknologi-dan-pengolahantelurasap-"lurik"-7918. (28 November 2018).

Keeton, J.T. 2001.Formed and Emulsion Product in: A. R. Shams (Ed).Poultry Meat Processing. CRC Press, Boca Raton.

Nafly, C.T., dan Veerman, M. 2011 Bahan pengenyal yang berbeda terhadap komposisi kimia, sifat fisik dan organoleptik bakso daging ayam. Agrinimal, 1(2), 76-83.

Sidi N.C., Widowanti, E., dan Nursiwi, A. 2014. Pengaruh penambahan karagenanpada karakteristik fisikokimia dansensoris fruit leather nanas (Ananas comosus L. Merr.) dan Wortel (Daucus carota). Jurnal Aplikasi Teknologi Pangan, 3(4), 122-127.

Sitanggang, D., Rusmarilin, H., dan Lubis, L.B. 2015. Pengaruh perbandingan bubur buah pepaya dan belimbing dengan konsentrasi karagenan terhadap protein bakso ikan pari dengan penambahan karaginan. Jurnal Media Gizi Pangan, 10(2), 21-25.

Suarti, B., Ramadhan, U., dan Fuadi, M. 2016. Pembuatan bakso dari biji lamtoro (Leucaena leucocephala) dengan penambahan putih telur dan lama perebusan. Agrium, 10(1), 308313. 